\title{
Accessing International Capital: Pakistan's Experience, Prospects, and Policy Implications
}

\author{
JAMSHED Y. UPPAL and I. U. MANGLA
}

\begin{abstract}
In the 1990s accessing international capital markets has become a major source of external financing for many developing countries. The paper reviews Pakistan's experience in tapping the global financial markets. We conduct a cross-sectional econometric analysis of the factors influencing the access to international equity and debt capital. Results indicate that the factors as suggested in the earlier literature do appear to be influential in determining the access to international capital. The study finds that the role of credit rating in attracting debt flows and of the local capital markets in attracting equity flows is prominent. The rate of economic growth is a major determinant of the access to foreign debt and equity funds. It also appears that the country rating which is based on a comprehensive set of variables indicating the financial health of the country subsumes the other proxies of economic stability and debt management. This study underscores the importance of institutional factors. Areas where improvement is possible to facilitate access to the international capital markets are identified as (1) political and legal environment, including improvements in the quality of the system of civil laws and its enforcement (2) private sector development through sustaining economic liberalisation and privatisation programmes (3) improvement in macro-economic management through a prudent internal and external debt management (4) development of capital markets through, improvements in market operations, enforcement of market regulations, strengthening of financial institutions and effective dissemination of market information.
\end{abstract}

\section{INTRODUCTION}

In the 1990s accessing international capital market for both equity and debt funds, has become a major source of external financing for many developing countries, commonly known as the emerging markets. The foreign portfolio investment (FPI), beside being a source of external financing, can have much broader beneficial impact on the capital markets and the economic development. FPI helps strengthen the domestic capital market, improves financial structure of developing country's corporations, enhances efficient allocation of resources, and induces greater domestic investment in real and financial assets. Besides, access to the international capital markets facilitates privatisation programmes and optimisation of capital structure of the private and the public sector corporations.

Jamshed Y. Uppal is Associate Professor, Department of Economics and Business, The Catholic University of America, Washington, D. C. I. U. Mangla is Professor in the Department of Finance and Insurance, Western Michigan University, Kalamazoo, Michigan. 
Although FPI is a promising source of resource funds, the ability to access the international capital markets has been highly differentiated. A few countries have been able to access the capital markets leaving most of the countries dependent on the traditional official sources. As access to the international capital markets is likely to become crucial for obtaining long-term resources for economic development [World Bank (1995)], there is an urgent need for the developing countries to undertake facilitating policy measures. It is, therefore, important to understand the nature of FPI, the conditions for easing access to the international capital markets and for maintaining continued flow of portfolio funds.

This paper examines the determinants of successfully accessing international capital markets in order to develop policy and operational measures. The next section discusses trends and patterns in the flow of resources to the developing countries. The following section presents results of an econometric exercise. The results of the empirical study are described in the next section, which is followed by discussion of policy implications and conclusions.

\section{DIFFERENTIATED ACCESS TO INTERNATIONAL CAPITAL}

Through 1980s official financial sources and commercial bank borrowing remained the dominant form of external financing for the developing countries, in the 1990s portfolio investment has emerged as the dominant form of resource flow. As can be seen in Table 1, in 1989 the total private debt and equity flows to the developing countries were $\$ 16.2$ billion; these flows increased to \$ 92.6 billion in 1993, and are estimated to have exceeded \$ 95 billion for 1994.

Table 1

Aggregate Net Long-term Resource Flow to Developing Countries

\begin{tabular}{lrrrrrr}
\hline \multicolumn{1}{c}{ \$ Billions } & 1989 & 1990 & 1991 & 1992 & 1993 & 1994 \\
\hline Aggregate Net Resource Flows & 84.5 & 103.4 & 124.2 & 153.0 & 213.2 & 227.4 \\
Official Development Finance & 42.6 & 57.9 & 61.9 & 50.3 & 53.9 & 54.5 \\
Total Private Flows & 42.6 & 45.5 & 62.9 & 102.7 & 159.2 & 172.9 \\
Foreign Direct Investment & 25.7 & 26.7 & 36.8 & 47.1 & 66.6 & 77.9 \\
Foreign Portfolio Investment & 16.2 & 18.8 & 26.1 & 55.6 & 92.6 & 95.0 \\
$\quad$ Private Debt Flows & 12.7 & 15.0 & 18.5 & 41.4 & 45.7 & 55.5 \\
$\quad$ Portfolio Equity Investment & 3.5 & 3.8 & 7.6 & 14.2 & 46.9 & 39.5 \\
\hline
\end{tabular}

Source: World Bank, World Debt Tables 1994-95.

Figure 1 provides a breakup of the total portfolio flows to the developing countries. The distribution of the portfolio flows is highly concentrated in a few countries suggesting a differentiated market access. As the figure shows, in 1993 over 
Figure 1

\section{Distribution of Total Portfolio Flows 1994}

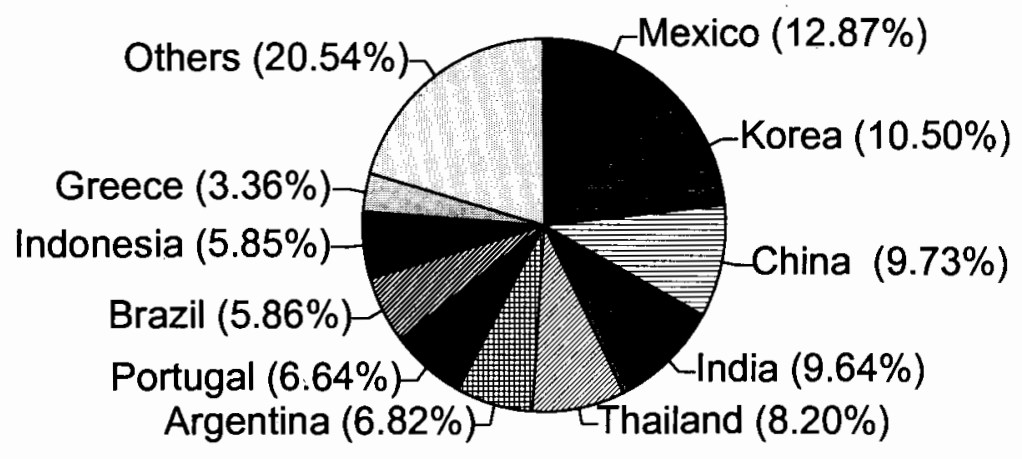

\section{Distribution of Total Portfolio Flows 1993}

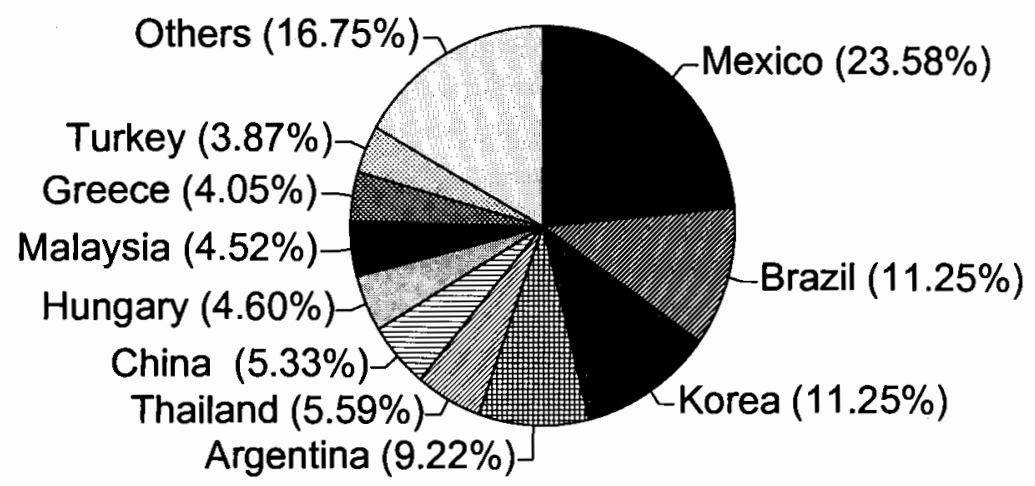


83 percent of the portfolio flows was concentrated in 10 countries; four countries, Mexico (24 percent), Brazil (11 percent), Korea (11 percent) and Argentina (9 percent) accounted for over 55 percent of the total portfolio flows. In 1994 the top ten recipients' share in the total portfolio flows, however, dropped to 79 percent, indicating a more even access to the international capital. Countries like India, Portugal and Indonesia increased their share considerably.

Although the distribution of portfolio flows in absolute amounts is highly concentrated, the flows have been more broadly spread relative to the size of the economies. The distribution of the ratio of the average annual flows over 1992-1994 to the GNP for 1994, however, shows a broader accessibility to the international capital.

\section{Pattern of Debt Flows}

Table 1 shows that the total private portfolio flows increased about 3.6 times, from $\$ 12.7$ billion to $\$ 45.7$ billion, over the 1989-93 period. About 64 percent of the 1993 debt flows were in the form of bond issues. Portfolio flows because of bond issues increased from \$ 5.3 billion in 1989 to \$ 42.1 billion in 1993, almost eight times over the period. In contrast there was a negative net long-term resource flow of \$ 2.2 billion from commercial banks [World Bank (1995a)]. The distribution of debt flows indicates a high degree of differentiated market access. In 1993 the share of ten countries in the debt flows was 87 percent, which decreased to 81 percent in 1994, again suggesting that the access to the international debt markets became more even.

\section{Pattern of Equity Flows}

As Table 1 shows portfolio equity flows to the developing countries increased from $\$ 3.5$ billion to $\$ 46.9$ billion by the end of 1993, increasing about 13 times. For the year 1994 the equity flows have been estimated at \$ 39.5 billion. As with the debt flows, a predominant share of the equity flows went to a few countries. In 1993 five countries (Mexico, Korea, Brazil, Malaysia and Argentina) accounted for 71 percent of the total equity flows. In 1994, however, the equity flows were more evenly distributed. Notable recipients have been India and China which significantly increased their share in 1994.

\section{PAKISTAN'S EXPERIENCE}

\section{Pakistan's Access to International Debt Markets}

Pakistan made beginning in accessing the external financial markets by offering foreign currency denominated deposits, namely, foreign currency deposits (FCDs), foreign exchange bearer certificates (FEBCs) and dollar bearer certificates 
(DBCs). These are geared in particular to the resident and non-resident expatriates. While the funds raised through these instruments have bolstered the balance of payment account, they have also rendered the capital account more sensitive to the relative interest rates. The maturity structure of these instruments is also not suitable for financing the longer term development requirements, for which long term bonds issued in the international markets are more appropriate instruments.

Foreign portfolio flows, especially debt flows, are quite sensitive to the perceived creditworthiness of a country. Pakistan's access to the international financial and commercial markets through the use of external instruments has been limited mainly due to investors' concern over country's creditworthiness. In view of the persistent balance of payment problems leading to soft rupee and minimal foreign exchange reserves a cautious approach by the international investors is natural. Absence of a solid track in the management of internal as well as external debt in the past has been cited as the reason for the lack of investors' confidence.

There are various debt issues in the pipeline, for example, Hub River Power Project (\$ 100 million), and Hydrocracker Project (\$330 million). Other possible debt issues in the international bond markets are linked to privatisation of public sector corporations like Pakistan Telecom, WAPDA, PNS, Sui Northern Gas. It is difficult to evaluate prospects for these issues in the international markets as these depend on the political and economic conditions and the credit rating of the issue and are hard to predict.

\section{Pakistan's Access to International Equity Markets}

Country funds have been an indirect channel for the international investors to invest in the countries' equity markets where there were significant restrictions on the foreign portfolio investment. Opening of the emerging markets to the foreign investors, removal of impediment in source countries, improvement in information flows and technological advancements have rendered the country funds not as crucial for accessing the international markets as before. Diwan et al. (1993), however, show that country funds traded in the developed capital markets can help promote the efficiency of pricing in the domestic markets and can enhance capital mobilisation by local firms. Country funds can, therefore, be useful even when entry and exit in the capital markets are unrestricted. More importantly, offering of well-structured country funds could be an effective first step to promote foreign investment in relatively less-sophisticated emerging markets.

Pakistan made a headway in establishing a presence in the international markets when the first country fund was set up by Citicorp in April 1991 with a capitalisation of \$ 22.6 million, which was listed on the Hong Kong Stock Exchange. Credit Lyonnais launched an open-ended growth \$ 25.7 million fund in November 1991, also listed in Hong Kong. A third country fund, \$ 6.1 million Special Situation 
Fund, was set up by Morgan Grenfell in April 1992. Another country fund is a joint \$ 60 million ten-year closed-end fund arranged by the Asian Development Bank with Morgan Stanley to be listed on the New York Stock Exchange. It is also understood that some regional funds have been targeted recently at Pakistani equities. Considering that in 1992 \$ 2.1 billion of new closed-end country regional funds investing in the emerging markets were issued, the Pakistani funds appear to be modest in size but are likely to be beneficial particularly in familiarising the international investors at the retail level to the Pakistani markets.

Pakistan made a debut in the international equity market as \$ 5.1 million of equity of the Balochistan Wheels Ltd. was privately issued in July 1992. Pakistan should further explore the possibilities of listing ADRs or GDRs internationally. There has also been a welcome beginning in international placements of equity issues, for example, N.A. Shah Bukhari's pre-IPO placement of \$ 2 million. Other international placements plans include Hub Power Co., Sitara Power, Koh-i-Noor Electric, and Gulistan Spring, among others.

\section{AN EXPLORATORY EMPIRICAL STUDY}

There has been little systematic collection of data on the amount of foreign portfolio flows to the emerging markets. The amounts of direct equity purchases by the foreigners in many cases are not tracked by the recipient countries. A lack of data on FPI has been one reason that there have not been many studies of the determinants of FPI to the emerging markets. Chuhan at el. (1994) have examined the role of global and country factors, in determining equity and bond flows to the emerging markets. To measures portfolio flows they used purchases of securities by foreigners reported to the U.S. Treasury by the financial institutions. The data, however, reports security purchases by foreigners and, therefore, the source of funds and not the destination. As such conclusions reached by the authors can not be relied upon.

Recently, more accurate and detailed data on the flow of portfolio funds over the period 1992-1994, when the FPI sharply increased, has been reported by the World Bank. Our study uses this data to examine the factors that may influence the flow of portfolio funds.

This study conducts a cross-section econometric analysis of the factors influencing the flow of FPI. The sample includes a group of 32 developing countries that have been successful in attracting FPI. The dependent variable is average annual portfolio flows over 1992-1994, total and broken down into bond and equity components, to the emerging markets normalised as a ratio to the countries' GNP. The choice of independent variables is suggested by existing literature. [e.g., see Drake (1986); Greenwood (1993); Gooptu (1993); Mullin (1993); Jun and Uppal (1995) and Williamson (1993)]. We settled on seven indicators representing broad categories of hypothesised determinants from a broader set of economic variables. 
(1) Credit-worthiness: To represent country's creditworthiness the study used the individual country rating by Institutional Investor. Institutional Investor's country ratings are based on grading by international banks assigned to each of the countries on a scale of zero to 100 . Besides, an indicator of external indebtedness is also used to proxy creditworthiness.

(2) Stage of economic development: The access to the international markets seems to depend on the stage of development of individual countries, proxied here by the income per capita. The per capita income is, however, used to control for heteroscadasticity in the residuals.

(3) Macroeconomic stability: Instability in the internal balances is indicated by fiscal deficits, and in external transaction by persistent current account deficits. We include as indicators of internal stability changes in the rates of inflation, and of external stability changes in the exchange rate.

(4) Economic growth: Growth is measured by rate of growth in GNP.

(5) Capital market development: The depth of the financial sector is proxied by the ratio of market capitalisation to the GNP, and rate of turnover in the stock market.

\section{EMPIRICAL RESULTS}

Table 2 shows the results from running three different multiple-regressions using as dependent variables total portfolio flows, total debt flows and total equity flows respectively. The regressor used were explained in section above. The method of estimation was weighted regression to control for heteroscadasticity, weighing factor being per capita income.

The second column in Table 2 shows that the coefficients of GNP growth and the country rating are statistically significant at 10 percent or better confidence level. As a determinant of debt flows, column 3 shows, only country rating appears to be a significant factor. As a determinant of equity flows, as shown in column 4 , the most significant regressor is the market capitalisation to GNP ratio. The other market related variable, market turnover ratio is also significant (p-value 6.4 percent). GDP growth is also significant with an achieved significance level of 3.7 percent. It is notable that the country rating is not a significant determinant for accessing equity flows.

Results of the study suggest that the factors pointed out by the earlier literature do appear to be influential in determining the flow of portfolio investment to developing countries. In particular the role of credit rating in attracting debt flows and of the local capital markets in attracting equity flows is prominent. The rate of economic growth is a major determinant of the access to FPI for both debt and equity funds. Other regressors do not apparently seem to effect accessibility of portfolio flows. It appears that the country rating which is a reflection of investors judgment on 
Table 2

Access to International Capital

\begin{tabular}{lccc}
\hline $\begin{array}{l}\text { Dependent Variable } \\
\text { Independent Variable }\end{array}$ & $\begin{array}{c}\text { All Issues } \\
\text { Coefficient }\end{array}$ & $\begin{array}{c}\text { Debt Issues } \\
\text { Coefficient }\end{array}$ & $\begin{array}{c}\text { Equity Issues } \\
\text { Coefficient }\end{array}$ \\
\hline Constant & -1.855 & -1.592 & -0.263 \\
& $(-1.214)$ & $(-1.144)$ & $(-0.481)$ \\
GDP Growth & $0.092^{* *}$ & 0.059 & $0.033^{* *}$ \\
& $(2.214)$ & $(1.562)$ & $(2.211)$ \\
Change in CPI & 0.003 & 0.004 & -0.001 \\
& $(0.706)$ & $(1.016)$ & $(-0.613)$ \\
Change in Exchange Rate & 0.000 & 0.000 & 0.000 \\
& $(-0.126)$ & $(-0.644)$ & $(1.284)$ \\
Debt/GNP & 0.025 & 0.022 & 0.003 \\
& $(1.342)$ & $(1.285)$ & $(0.479)$ \\
Market Capitalisation/GNP & -0.001 & -0.008 & $0.006^{* * *}$ \\
& $(-0.196)$ & $(-1.391)$ & $(2.989)$ \\
Market Turnover Ratio & 0.004 & -0.003 & $0.007 *$ \\
& $(0.367)$ & $(-0.361)$ & $(1.942)$ \\
Country Rating & $0.054^{*}$ & $0.056^{* *}$ & -0.002 \\
& $(1.850)$ & $(2.121)$ & $(-0.226)$ \\
Adjusted $R$-squared & 0.21 & 0.15 & 0.38 \\
Durbin-Watson & 1.95 & 1.85 & 1.76 \\
$F$-statistic & 2.17 & 1.78 & $3.68^{* *}$ \\
\hline
\end{tabular}

Note: $T$-statistics are given in parentheses; $*$, **, and $* * *$ denote significance at 10 percent, 5 percent and 1 percent respectively.

a comprehensive set of variables indicating the financial health of the country subsumes the other proxies of economic stability and debt management.

\section{POLICY IMPLICATIONS}

Our analysis identifies many areas where improvement is possible to facilitate access to the international capital markets. It suggests that many countries need to adopt more aggressive measures to attract foreign portfolio investment.

\section{Credit-worthiness}

The capacity to issue bonds in the international markets seems to be determined largely by the creditworthiness consideration. Availability of credit rating lowers the information cost for the investors, thus lowering the cost of capital and also broadening the investors base for the borrower. From the international investors' 
point of view, both the credit rating of the country and the rating received by the particular issue are important. Individual countries are rated by many official agencies, e.g., Moody's and Standard and Poor's. In the absence of formal rating, country creditworthiness is often assessed with respect to a proxy rating system such as one followed by Institutional Investor. Although, a formal rating is not a necessary condition for successfully launching debt issues, without ratings international investor base tends to be limited because many institutional investors are constrained to invest in rated issues.

Credit-worthiness reflects the overall political and economic factors that may influence the country's willingness and ability to repay debt obligations. Rating agencies such as Standard and Poor's and Moody's consider a broader set of variables effecting a country's creditworthiness, broadly classifying the country's risk into political and economic risk. While political risk focuses on the political system, social environment and international relations, economic risk focuses on the external financial position, balance of payment flexibility, economic structure and growth, external trade performance, and overall economic management. Long term measures toward improvements in social conditions and political stability are as important as improvements in the external indebtedness and liquidity. Strong macroeconomic policies, in particular in the management of external debt, lead to a gradual buildup of foreign reserves and consequently to an improvement in the country's creditworthiness.

The empirical model has not been able to fully explain all of the variation in the accessibility to foreign portfolio flows. This points out to the possibility that many institutional factors are not being captured by our model. The major institutional areas that deserve attention are: (1) political and legal environment, including improvements in the quality of the system of civil laws and strengthening the enforcement of the corporate and securities laws (2) private sector development through sustaining economic liberalisation and privatisation programmes (3) improvement in macro-economic management through a prudent internal and external debt management. A key element of sound macro-economic management is greater autonomy and technical capabilities on part of the central banks (4) development of capital markets through, improvements in market operations, enforcement of market regulations, strengthening of financial institutions and effective dissemination of market information.

\section{Political and Legal Environment}

Political uncertainty is detrimental to any investment, as it adversely affects economic activity and hence the expectations of the investors. Improvements in the general law and order situation will greatly help stable growth of financial markets. A healthy private sector requires an adequate legal framework and transparent tax 
codes. Vibrant private sectors in the Asian and Latin American countries, have been instrumental in accessing international capital flows while rudimentary corporate governance systems have been an impediment for the countries of Eastern Europe and the former Soviet Union. Experience of a number of countries (e.g., Egypt, Hungary and Venezuela) shows that improved legal framework and investment codes are a key factor in attracting capital inflows.

The quality of the system of civil laws plays a fundamental role. Securitisation of assets is hardly possible without enforceability of contracts. A legal system which not only allows for a clear definition of the rights and responsibilities of the contracting parties but also provides for cost-effective enforcement of covenants is a precondition for the development of securities markets. Strengthening the enforcement of the corporate and securities directly affords protection to the portfolio investors against agency problems. Most of the publicly traded firms in Pakistan are closely held and there is a widespread suspicion that the corporate insiders do not act in the best interest of the outside shareholders. An effective mechanism for corporate control as a deterrence to the moral hazard and agency problem does not exist. For example, it is widely recognised that many companies conceal income for avoiding taxes to the detriment of the minority shareholders.

\section{Sustained Economic Development}

The access to the international markets seems to depend on the stage of development of individual countries. Most of the successful countries have been less indebted-middle income countries, though Indonesia and India fall in the category of moderately indebted-low income countries as does Pakistan. China is classified as a less indebted-low-income country. Credit rating of China and Indonesia is, however, far stronger than countries that have not attracted much FPI. The large amounts of FPI (and also FDI) to China have been attracted by the country's remarkable economic performance, among other factors, in the recent years.

There now appears to be a consensus that economic development can best take place in a free-market environment, supported by a well-functioning private sector. Pakistan has made strong progress in its privatisation programme and in liberalisation of foreign trade and investment regimes. The private sector vigorously responded to the new economic environment as evidenced by strong GDP and export growth. Experience of Pakistan and other countries, e.g., Chile and Korea, has shown that the removal of exchange controls generates increased investor confidence and stimulates investment flows. Privatisation also plays a direct role in the development of the markets by increasing the supply of securities. At the same time without an efficient equity market full benefits of privatisation can not be achieved. Further steps should be taken towards active private sector development, in conjunction with enabling privatisation programmes and a reduction of public sector's direct role by way of active privatisation. 


\section{Macroeconomic Environment}

A stable macroeconomic environment is essential for the mobilisation of saving and increasing domestic investment levels, whether foreign or domestic, FPI or FDI. Sustained implementation of sound macroeconomic policies are also fundamental for establishing creditworthiness. The recent experience of Latin American countries (e.g., Argentina and Mexico) suggests that financial market flows respond quickly to improvements in creditworthiness.

Another area of concern is the external imbalance resulting from persistent current account deficits, coupled with large fiscal deficits. Sound macroeconomic management will also lead to a stable exchange rate which will reduce the currency risk for foreign investors. There is a need to adopt fiscal and monetary disciplines to ensure lower inflation, positive real interest rates and sustained growth in saving, and a stable and realistic foreign exchange rate. This could be affected through improved external debt management, a reduced size of public deficit and market discipline in the public financing.

A vigorous and independent regulatory body is essential for conducting monetary policy purely on economic considerations, for ensuring market orientation in the conduct of monetary policy, financial health and efficiency of financial institutions and markets, and for imposing monetary and fiscal discipline on the public sector.

\section{Capital Markets Development}

One policy implication of our empirical results is that for developing countries for which immediately improvement in credit ratings is not possible, development of local capital markets may offer a way to attract equity investment.

Pakistan has been largely successful in implementing a financial sector adjustment programme. The introduction of auction programmes for treasury bills and federal investment bonds together with the development of a framework for primary dealer network and the secondary market has been an important step in developing the financial markets. A balanced growth in the money markets is desirable as they supplement the capital markets and development in one should lead to development in the other. Along with the development of the public debt market, the corporate debt market needs to be developed which will provide expanded financing options for the private enterprises. Much of the corporate debt is being held by the banks with an undetermined market value. An active secondary market in the corporate debt will provide liquidity to the banks and would reflect the intrinsic economic cost of debt. The financial institutions must operate with clear market discipline. Ensuring financial soundness, efficiency and competitive strength of banks and non-banks will enhance their capability to intermediate resources through financial markets. 
Capital markets in Pakistan will be greatly strengthened by improving the implementation and enforcement of regulation. A lingering suspicion of insidertrading practices can destroy investor confidence in the market and can be fatal to the development of sound financial markets. Enforcement of regulation for the prevention of insider trading, broker fraud and abusive practices, and for ensuring market transparency require greater technical expertise and ingenuity than has conventionally been practised by the public sector. On the other hand, market based deterrence against such irregularities can be strengthened by improving dissemination of market information, and quality of security analysis.

\section{CONCLUSIONS}

Recent years have witnessed fundamental changes in the pattern of external finance for developing countries. In this process, portfolio investment-both equity and bond-has been an increasingly important form of resource flows. This trend, which is likely to continue, suggests that the access to the international financial markets will become crucial to the availability of external resources for meeting development needs. The high degree of differentiation in the market access points out to the necessity of achieving and maintaining an acceptable level of creditworthiness in the international markets. Recent experience also shows that an improvement in economic prospects, resulting from sustained structural adjustments, and prudent financial management of internal and external balances, can be achieved in a relatively short period of time and is often quickly rewarded by financial markets.

The apparent competition among developing countries to attract foreign capital is very intense. In addition to institutional and economic measures discussed above, there is a need to make concerted efforts to disseminate market information to potential investors abroad. A coherent and integrated approach to market the country based on providing pertinent and timely information to the international investors is required. It appears that for many developing countries that have had a limited success in attracting FPI the prospects of enhancing the access to the international capital markets in the near and long-term future can be dramatically improved, provided suitable policies are carried out.

Pakistan has made considerable progress in moving towards a market-based economy, by privatisation, liberalisation of trade and foreign exchange and opening of its capital markets for foreign investors, but our analysis suggests a number of areas where improvement is needed to facilitate FPI. Experience of Pakistan, and of

other developing countries, indicates that more aggressive measures to attract foreign portfolio investment are warranted. 


\section{REFERENCES}

Chuhan, Punam, Stijn Claessens and Nlandu Mamingi (1993) Equity and Bond Flows to Asia and Latin America-The Role of Global and Country Factors. Washington, D. C.: The World Bank. (Working Paper No. 1160.)

Drake, P. J. (1986) Capital Markets, Mobilising Resources for Development. Washington, D. C.: International Finance Corporation.

Gooptu, Sudarshan (1993) Portfolio Investment in Emerging Markets. Washington, D. C.: The World Bank. (World Bank Working Paper No. 1117.)

Greenwood, John G. (1993) Portfolio Investment in Asian and Pacific Economies: Trends and Prospects. Asian Development Review 11: 121-150.

Institutional Investor (Various Issues) Country Credit.

Jun, Kwang W., and Jamshed Y. Uppal (1995) Portfolio Flows to Pakistan: Trends and Policies. In Ahmed and Hafeez (eds) Private Sector Development in Pakistan. Lahore: Maktaba Jadeed Press 46-83.

Mullin, John (1993) Emerging Equity Markets in the Global Economy. FRBNY Quarterly Review (Summer): 54-83.

Treasury Bulletin (Various Issues) Foreign Purchases and Sales of Long-Term Securities, by Type and Country, Capital Movement Section. Table CM-V4.

Uppal, Jamshed Y. (1996) Portfolio Flows to Emerging Markets: Prospects, Pitfalls and Policy Implications. Journal of Asia-Pacific Business. (Forthcoming.)

Williamson, John (1993) International Capital Markets: Trends, Prospects and Issues. A paper presented at the Third Seminar on International Finance. New Delhi: Institute of International Economics: Washington, D. C. (August).

World Bank (1995) Global Economic Prospects and the Developing Countries-1995. Washington, D. C.: The World Bank.

World Bank (1995a) World Debt Tables, 1994-1995. Washington, D. C.: The World Bank. 